\title{
Implementation of 2013-Curriculum with a Scientific Approach at SMPN 2 Merauke
}

\author{
Inggrid Marlissa \\ Musamus University \\ Merauke, Indonesia \\ marlissainggrid@gmail.com
}

\author{
Juliana R. Untayana \\ Musamus University \\ Merauke, Indonesia
}

\begin{abstract}
The purpose of this study was to describe the substance of 2013-curriculum in Junior High School and its implementation on math learning in junior high school. This study was a using qualitative approach which is located in State Junior High School 2 of Merauke. The instrument used to collect data is a guideline for observation, interview, questionnaire, and documentation study. The data analysis that used in this research is descriptive-qualitative by giving a logical narrative based on the research goal. The process of data analysis in qualitative research conducted since before into the field, while in the field, and after its completion in the field. The results showed that in the planning process, the teachers write lesson plans in which outlines the scientific approach to operational measures. The implementation of learning is not maximal, one of the stages that are still difficult to apply is the activity of reasoning. The teachers already use to assess the cognitive, effective, and Psychomotorik.
\end{abstract}

Keywords--scientific approach; the 2013-curriculum

\section{INTRODUCTION}

One of the efforts undertaken by the government to produce qualified human resources and adjust the development of the times is to curriculum development. The curriculum of 2006 (KTSP) developed and updated into Curriculum 2013. However, after Curriculum 2013 simultaneously began to apply throughout Indonesia in the academic year 2014/2015, it turns out Curriculum 2013 still has weaknesses that need to be reviewed. Based on this, the government issued a circular minister followed up with the issuance of Permendikbud Number 160 of 2014 on the implementation KTSP and Curriculum 2013.

The 2013 curriculum applies scientific learning approach. The scientific approach is believed to be an effort in promoting the development and development of cognitive, affective and psychomotor of learners. In the approach or work process that meets the scientific criteria, the scientists put forward inductive reasoning rather than deductive reasoning [1].

In line with the above, ref [2] states that: "systematic process for acquiring new knowledge that uses the basic principle of deductive (and to a lesser extent inductive) reasoning. It's considered the most rigorous way to elucidate cause and effect, as well as discover and analyze less direct relationships between agents and their associated phenomena".

The learning process in the 2013 curriculum for all level is carried out using a scientific approach. The learning process must consist three domains, such as of cognitive, affective and psychomotor. The end result is an increase and balance between the ability to be a good human (soft skills) and human beings who have the skills and knowledge to live properly (hard skills) of learners that includes aspects of attitude, skills, and knowledge competencies. The 2013 curriculum emphasizes on the modern pedagogical dimension that using a scientific approach [1].

Refference [3] defines a scientific approach is a learning approach that is done through observing, questioning, experimenting, associating, and communicating. In line, more overs [4] states that in the scientific process, students construct knowledge by questioning, observing, measuring, collecting data, estimating results, conducting experiments, concluding and communicating.

The scientific approach is relevant to the standard of mathematics learning junior high school level. "Reference [5] describes the standards of learning mathematics junior namely: (1) students must be actively involved related to the ability to locate and define structure, (2) suspect and verify, (3) think about the hypothesis, (4) understand the cause and effect, (5) abstraction and draw conclusions.

Based on observations, Junior High School which has implemented the 2013 curriculum since the academic year 2103/2014 only SMP Negeri 2 Merauke. Furthermore, based on the results of interviews with mathematics teachers, teachers do lesson planning by making the lesson plan itself but still have difficulty when making RPP. For the learning process, the teacher said that the learning process has been using a scientific approach but still have constraints other than that the stages contained in the scientific approach have not been implemented optimally by the students.

\section{METHODS}

This research used qualitative natural condition approach to describe a phenomenon in the research based on the results of 
collecting observation data, interviews, questionnaires, documentation and researchers as their key instrument.

Qualitative research often referred to as naturalistic research methods since research do in natural conditions. The characteristic of this research is descriptive qualitative. The form of data collected are words or images, so would not only use the numbers.

In this study, the data analysis used descriptively-qualitative with a logical narrative according to research necessity. The process of data analysis in qualitative research conducted before during and after research in the class.

\section{RESULTS AND DISCUSSION}

\section{A. Learning Planning}

Learning planning activities undertaken by the teacher are studying the syllabus, reviewing the teacher book, and arranging the lesson plan. Before concluding the learning process, the teacher first makes learning device in the form of RPP. The teacher has made RPP for one semester, so the teacher does not make RPP every day. Based on the results of the interview, it can be seen that the teacher makes his own RPP. The principal's statement in the interview notes provides reinforcement that the teacher makes his own lesson before the school year begins. Making RPP for 3 days in the workshop.

The first step in learning is learning plan embodied by drafting Learning Implementation Plan (RPP).Based on the results of RPP document analysis made by teachers, the components are in accordance with appendix permendikbud, while for the results of RPP analysis, and the teacher has described the scientific approach to RPP.

The teacher describes a scientific approach to core activities that includes observing, questioning, gathering information/trying, associating/ communicating, and communicating $(5 M)$. Stages of $5 M$ activities in RPP are not sequential. Based on the results of the RPP analysis, the teacher also gave a specific description of the activity which is the $5 \mathrm{M}$ activity, by way of giving the activity information in parentheses. However, this information is only part of the activity. Even in one RPP is not fully written from observing activities to communicating.

\section{B. Implementation of Learning}

Teachers are already implementing the lesson as planned in RPP. Although there are still activities or learning materials that have not been delivered due to insufficient time allocation. Supportive school facilities are still minimal, but with the ability to empower what exists, such as computer labs, the use of LCD every teacher entering the classroom.

\section{1) Introduction Activities}

Based on the observation, the learning activities undertaken by the teacher in the preliminary activities, includes conditioning a fun learning atmosphere, initiate the activity with prayers and sing the national songs further discuss the competencies that have been studied, convey the competence to be achieved, and conveying the scope and assessment techniques to be using.

\section{2) Core Activities}

Based on observations, interviews, and documentation, it was found that the core activities of the teachers highlighted 5M activities. The 5M activity in the Scientific Approach involves observing, questioning, gathering information/trying, associating/ reasoning, and communicating. It is also conveyed by the principle that the teacher is doing the learning refers to the learning steps that have been made in the lesson plan, for the implementation of the curriculum of 2013 students have been grouped, at least one class there are 5 study groups and then the activity is always focused on the students so that the teacher only becomes the facilitator. So that in the group work must be presented by the students because the school has started to apply school literacy movement.

Based on the results of research, there are still activities or learning materials that have not been delivered due to insufficient time allocation. Teachers should manage time well because a teacher is required to be able to manage the time effectively so that student learning time is met [6].

During the learning process, the teacher has also invited students to be taken out of the classroom. This is in line with the scientific approach of making the students' learning experience more relevant and meaningful in building the knowledge they will apply in the experience of a lifetime. In line with this, [7] states that it is because the subject matter given will be more meaningful, in accordance with the context of their daily lives to produce optimal efficiency.

Observing activities conducted by students with guidance from teachers. The teacher has prepared a student activity sheet, which will be used in the learning process, besides the students also use the student's book.

Student's activity is not only directed from teacher to student, but also from student to teacher. This can be seen from the question and answer activities conducted by students and teachers. There are students who actively ask, but there are also students who have not dared to ask. Sometimes, students who are not accustomed to inquiring are busy alone or annoying other students. The role of teachers is necessary for guiding students by giving individual questions.

Furthermore, students collect data in groups with activity guide sheet provided by the teacher. Other sources are also used by students such as student books and other sources. During the discussion, the teacher guides and assists students in conducting discussions within the group. This is because the students still cannot discuss themselves.

In the implementation of learning by using a scientific approach, activities that are considered difficult to do is the activities of reasoning. Information has been obtained, 
students are difficult to process and link related information in order to find a pattern or formula that is derived.

In communicating activities, the teacher asks students to write their own work on the board. While students from other groups commented on the results written by his friend. In addition to developing the ability to express opinions communicating activities can also increase the courage and confidence of students when displaying the work in front of the class.

\section{3) Closing Activities}

Based on the observation result, in closing activities the teacher performs activities such as making summary/conclusions of the lesson, reflecting, giving feedback, planning follow-up activities, conveying lesson plans at the next meeting, and providing homework.

\section{Learning Assessment}

Assessment is done during the learning process takes place. The assessment runs during the learning process because there is an assessment of attitudes, skills, and knowledge. The assessment instruments used to assess student learning outcomes are made by the teacher themselves. The tests used for the assessment consist of daily examination, midterm and final exam of the semester.

On the other hand, teachers experience obstacles in planning, implementing and teaching-learning activities. In learning planning, teachers have difficulty in developing learning steps using the Scientific Approach and assessment instruments. This is due to a lack of understanding of teachers about the importance of developing learning activities.

Obstacles encountered by teachers in the implementation of learning is teachers are less in doing variations in learning activities using a scientific approach. This is due to the lack of motivation of teachers to make variations of learning activities. Teachers only carry out activities contained in the teacher's book only. These less varied activities make students less enthusiastic in following the lesson.
Furthermore, the obstacles that teachers encounter in the assessment of learning are the many aspects that should be assessed in the Curriculum assessment of 2013, so the teacher takes a long time to do the assessment. Efforts by teachers to overcome these obstacles is to immediately reap the value of students not to accumulate and complete the assessment after the learning process ends. In addition, to facilitate the final assessment, the school has created a program used to calculate the final value.

\section{CONCLUSION}

Based on the results of research and discussion, this study can be summarized as follows: Teachers have planned learning activities, implementing learning using scientific approach but observing activities, asking, gathering information / trying, associating / reasoning, and communicating have been done but still not maximized. Activities that are considered difficult is the activities of reasoning. Authentic assessment has also been used by teachers to assess the competence of attitudes, knowledge, and skills.

\section{REFERENCE}

[1] Kemendikbud, Materi pelatihan guru implementasi kurikulum 2013

[2] Untajana. J. R \& Harta. I, "Pengembangan Perangkat Pembelajaran Limit Berbasis Pendekatan Saintifik Berorientasi Prestasi Belajar dan Kemampuan Komunikasi Matematika” JRPM, vol 3, pp 45-54, Mei 2016.

[3] Fadlilah, M. Implementasi Kurikulum 2013 Dalam Pembelajaran SD/MI, SMP/MTs, \& SMA/MA. Yogyakarta: Ar-Ruzz Media., 2014

[4] Martin, D. J. Elementary Science Methods: A Constructivist Approach, Fourth Edition. USA: Thomson Wadsworth 2006

[5] NCTM. Principles and standards for school mathematics. Reston, VA: NCTM, Inc, 2000.

[6] Hosnan M. Pendekatan Saintifik dan Kontekstual Dalam Pembelajaran Abad 21 Kunci Sukses Implementasi Kurikulum 2013. Jakarta: GhaliaIndonesia, 2014

[7] Lawson, Anton. Science Teaching and the development of thinking. California: Wadsworth Publishing Company, 1995 